\title{
The role of folate receptor and reduced folate carrier polymorphisms in osteoporosis development
}

\author{
ALEKSANDRA E. MROZIKIEWICZ ${ }^{1}$, ANNA BOGACZ ${ }^{* 2,3}$, MAGDALENA BARLIK $^{4}$, ALEKSANDRA \\ GÓRSKA ${ }^{3}$, MARLENA WOLEK ${ }^{3}$, MAŁGORZATA KALAK ${ }^{5}$
}

\author{
${ }^{1}$ Division of Infertility and Reproductive Endocrinology \\ Poznań University of Medical Science \\ Polna 33 \\ 60-535 Poznań, Poland \\ ${ }^{2}$ Department of Histocompatibility with Laboratory of Genetic Diagnostics \\ Regional Blood Center \\ Marcelińska 44 \\ 60-354 Poznań, Poland \\ ${ }^{3}$ Department of Stem Cells and Regenerative Medicine \\ Institute of Natural Fibres and Medicinal Plants \\ Kolejowa 2 \\ 62-064 Plewiska, Poland \\ ${ }^{4}$ Division of Perinatology and Women's Diseases \\ Poznań University of Medical Science \\ Polna 33 \\ 60-535 Poznań, Poland \\ ${ }^{5}$ Molecular Genetics Laboratory \\ GenXone S.A. \\ Kobaltowa 6 \\ 62-002 Złotniki, Poland
}

*corresponding author: e-mail: aniabogacz23@o2.pl

\section{Summary}

Introduction: Osteoporosis is a chronic metabolic disease with multifactorial etiology. One of possible osteoporosis causes may be impairment of osteoclasts function which leads to increased bone resorption. This 
may be a result of many metabolic changes. It is believed that changes of folate-methionine metabolism in osteoporosis play an essential role in the etiology of this disease.

Objective: The aim of this study was to examine how polymorphisms of SLC19A1 and FOLR3 genes may play the key role in folate-methionine pathway and influence on the etiology of osteoporosis.

Results: The statistically overrepresentation of mutated GG genotype of FOLR3 (rs11235449) was observed in the control group compared to the osteopenia ( $34.9 \%$ in osteopenia vs. $37.8 \%$ in controls, $p=0.025$, $\mathrm{OR}=0.61$ ). As to the SLC19A1 (rs3788200) polymorphism we have noted the statistically significant overrepresentation of wild-type GG genotype $(35.8 \%$ vs. $26.2 \%, p=0.046, \mathrm{OR}=1.57)$ and overrepresentation of wild-type $\mathrm{G}$ allele $(56.9 \%$ vs. $50.2 \%, p=0.061, \mathrm{OR}=1.31$ ) in osteopenia group if compared to the controls.

Conclusions: In our study we shown the protective role of mutated GG genotype of FOLR3 (rs11235449) polymorphism to osteopenia progress and possible role of wild-type GG genotype and wild-type G allele of SLC19A1 (rs3788200) polymorphism in osteopenia development.

Key words: osteoporosis, osteopenia, folate-methionine metabolism, SLC19A1, FOLR3

Słowa kluczowe: osteoporoza, osteopenia, metabolizm folianów i metioniny, SLC19A1, FOLR3

\section{INTRODUCTION}

Osteoporosis is a chronic metabolic disease of multifactorial etiology. One of possible osteoporosis causes may be the impairment of osteoclasts function what leads to increased bone resorption. This may be a result of many metabolic changes.

Osteoporosis is 3 -fold more often diagnosed at women what is partially caused by low peak bone mass and hormonal changes observed in postmenopausal women. In the Report of World Health Organization Scientific Group from 2003, osteoporosis was recognized as a well-defined disease or disturbance concerning 75 million of people in Europe, Japan and USA and is a reason of over than 2.3 million of breakages in Europe and USA [1].

Proper folate metabolism is strictly correlated with not disturbed development and functioning of human organism. Any perturbation in folate cycle may lead to many complications in cardiovascular system, nervous system and neoplasms. Well balanced folate cycle has a vital influence on proper functioning of hematopoetic, nervous and cardiovascular system and reduces the risk of thrombotic events.

Folic acid, due to its high biological activity, has both direct and indirect effects on the metabolism of body's cells. Deficiency or lack in the diet causes disorders in many vital metabolic processes and may lead to impaired growth and development of human organism. The rich source of folates in daily diet are plant products. The richest are greenleaf vegetables. Large amounts of folates contain legume seeds. Significant amounts of folate are also found in yeast, whole cereal grains and wheat germ. Very good sources are vegetables and fruits also containing vitamin $\mathrm{C}$ or $\beta$-carotene. In food, folic acid is predominantly methylated in form of L-5-methyl-THF.

It is believed that folate status could modify the risk of osteoporosis development. Variants of genes involved in proper function of folate cycle could be the candidate genes for osteoporosis and osteopenia development. One of the most important roles in folate metabolism is played by genes encoding transport proteins, they mainly maintain intracellular folate level. It is known that FOLR1 and FOLR2 are glycosyl phosphatidylinositol proteins and anchored proteins. The FOLR3 is a secreted receptor protein, SLC12A1 is a transmembrane protein, SLC19A1 gene is located on 21q22.3 chromosome and encodes one of the most important link of metabolism cycle, SLC19A1 functions as anion accepting folate cofactors and exporter of many organic anions. These gene is composed of 5 exons and contains open reading frames (ORF) [2].

FOLR3 (Folate Receptor 3) is a protein encoding gene. It encodes a folate receptor with high affinity for folic acid and other folate derivatives. It is located on chromosome 11 and has many variants.

It is believed that changes of folate-methionine metabolism in osteoporosis play an pivotal role in the etiology of this disease. On the above-mentioned we hypothesized that polymorphisms of SLC19A1 and FOLR3 genes may play the key role in 
methionine-folate pathway and influence the etiology of osteoporosis [2,3].

\section{MATERIAL AND METHODS}

\section{Study design}

The 109 unrelated postmenopausal Caucasian women (mean age: 53.24 \pm 8.12 ) with osteopenia and 333 patients with osteoporosis (mean age: $56.06 \pm 8.83$ ) were enrolled into study. The control group consisted of 233 postmenopausal women with normal T-score (mean age: $53.38 \pm 8.22$ ). Local Ethical Committee consent (No 158/06) for performing the study was given. All women were Caucasian of Polish origin. All of them were informed about the goal of study and given their consent.

All subjects passed densitometry examination at lumbar spine (L2-L4) by dual energy X-ray absorptiometry (DEXA). From each woman data about body weight, height, and years since menopause (YSM) have been collected. We have analysed body mass index (BMI) according to WHO criteria (normal BMI 18.9-24.9 kg/m², overweight 25.0 $29.9 \mathrm{~kg} / \mathrm{m}^{2}$, and obesity - higher than $30.0 \mathrm{~kg} / \mathrm{m}^{2}$ ). Bone mineral density (BMD), $t$-score, $z$-score, the percent of young adults (YA) index, and aged matched (AM) index measured in L2-L4 were given as result of densitometric evaluation. Densitometry was performed using the LUNAR DPX 100 camera (Lunar Corp., Madison, USA).

The correct value of the BMD by DEXA is between one standard deviation from the mean with respect to the age of peak bone mass $(-1<\mathrm{T}$-score $>$ $1)$. Based on these measurements, the women were classified into group with osteopenia $(-2.5<$ T-score $\leq 1$ ), osteoporosis (T-score $\leq 2.5$ ) and with the correct value of the $\mathrm{T}$-score (T-score $\geq 1$ ). The ratio of the average bone mineral density in relation to mean value for young adult (young adults, YA) and in comparison to age (age matched, AM) was also evaluated. Furthermore, the height and weight measurements were performed and the body mass index (BMI) was calculated. During an interview with each patient, the data concerning the occurrence of disease, drugs used, age of first and last menstruation, number of pregnancies and birth weight of children were collected.

Inclusion criteria for genetic research were: menopause at least a year before, no hormone replacement therapy (HRT) and drugs affecting bone mass (selective estrogen receptor modulators SERMs, calcitonin, bisphosphonates, heparin, steroids, thyroid hormones, antiepileptic drugs, $\mathrm{GnRH}$ analogues, tibolone).

Patients with endocrine and metabolic disorders, hematological diseases, kidney disease, cancer, autoimmune and connective tissue disease and after bilateral ovariectomy were excluded from the study.

\section{Expression analysis}

The analysis of the FOLR3 and SLC19A1 gene polymorphism was conducted at the Department of Stem Cell and Regenerative Medicine, Institute of Natural Fibres and Medicinal Plants, Poznań, Poland. Genomic DNA was extracted from peripheral blood using QIAamp Blood Kit (Qiagen GmbH, Hilden, Germany) according to the manufacturer's protocol.

The genetic analysis of FOLR3 and SLC19A1 genes was performed using LightCycler 96 instrument. The rs11235449 polymorphism in the FOLR3 gene and the rs3788200 polymorphism in the SLC19A1 gene were performed using LightSNiP FOLR3 and SCL19A1 (TIBMolbiol), which contained the primers and probes specific for the amplified fragments. PCR was performed in $10 \mu \mathrm{l}$ reaction mixture according to the manufacturer's protocol under the following conditions: initial denaturation at $95^{\circ} \mathrm{C}$ for $10 \mathrm{~min}$., and 35 cycles as follows: denaturation at $95^{\circ} \mathrm{C}$ for $10 \mathrm{~s}$, annealing at $60^{\circ} \mathrm{C}$ for $10 \mathrm{~s}$, elongation for $15 \mathrm{~s}$ at $72^{\circ} \mathrm{C}$, and melting step of $30 \mathrm{~s}$ at $95^{\circ} \mathrm{C}$ and $40 \mathrm{C}$ by $120 \mathrm{~s}$. Polymorphism FOLR3 and SCL19A1 genes were observed as different melting curves of PCR products.

\section{Statistical analysis}

Data analysis was performed using SPSS Statistics 17.0 for Windows using one-way ANOVA test. The observed frequencies were compared with expected frequencies and tested for the Hardy-Weinberg equilibrium. The expected results are presented with 95\% confidence intervals (CI). We also calculated the odds ratio (OR) for the genotypes and the alleles. The value of $p<0.05$ was considered as statistically significant.

\section{RESULTS}

In the investigated women with osteoporosis the statistically differences connected with T-score 
$(p<0.001)$ and Z-score $(p<0.001)$ values as well as body weight $(p=0.001)$, BMI $(p=0.04)$, age $(p=0.014)$, birth weight $(p=0.005)$ have been observed if compared to the women with osteopenia and controls. We have not observed any differences in BMD L2-L4, BMD L2-L4 YA, BMD L2-L4 AM values between investigated subgroups of women with osteoporosis, osteopenia and controls (tab. 1).

The statistically overrepresentation of mutated GG genotype in the control group if compared to the osteopenia $(34.9 \%$ in osteopenia $v$ s. $37.8 \%$ in controls, $p=0.025, \mathrm{OR}=0.61$ ) has been observed. The other genotypes (homozygous AA and heterozygous AG) as well as the alleles were in similar frequencies. In the osteoporosis group we have observed the similar frequencies of genotypes and alleles of investigated FOLR3 (rs11235449) polymorphism (tab. 2).

As to the SLC19A1 (rs3788200) polymorphism we have noted the statistically significant overrepresentation of wild-type GG genotype (35.8\% vs. $26.2 \%$, $p=0.046, \mathrm{OR}=1.57)$ and overrepresentation of wildtype $\mathrm{G}$ allele $(56.9 \%$ vs. $50.2 \%, p=0.061, \mathrm{OR}=1.31)$ in osteopenia group if compared to the controls. The other frequencies of genotypes and alleles of SLC19A1 (rs3788200) polymorphism in osteopenia as well as in osteoporosis groups were similar (tab. 3).

\section{DISCUSSION}

Several risk factors for osteoporosis development have been identified such as age, low body mass index, smoking, alcohol intake and low bone mass density. It was also already indicated that folate deficiency results in increased serum level of homocysteine which disturbs proper bone metabolism. Homocysteine probably is responsible for accumulation of collagen in bones what leads to decrease of bone strength [1]. The exact mechanisms of homocysteine influence on bone turnover still remains unclear. It is thought that increased level of homocysteine impairs proper balance of osteoclasts and osteoblasts with harmful effect for bone mineralisation [2]. Proper functioning of folate receptors is vital for well-balanced folate cycle what leads to decrease of homocysteine concentration. And homocysteine lowering favorably influences the risks and course of osteoporosis [4].

Increased level of homocysteine is also positively correlated with bone fracture risk. So probably folate supplementation at post-menopausal women may modify homocysteine serum concentration and what is more important may influence on the risk of bone fracture [5]. The aim of many present studies was to investigate the association between high serum homocysteine level, decreased bone mineral density and increased risk of bone fractures $[6,7]$.

Observed results of large epidemiologic researches showed correlation between increased serum homocysteine concentration and high risk of osteoporotic fractures [8-10]. Moreover, increased homocysteine level may lead to excessive bone resorption $[11,12]$. One of the studies based on the National Health and Nutrition Examination Survey revealed that increased plasma homocysteine concentration and folate insufficiency are correlated with lower lumbar and overall bone mineral density [13].

The correlation between osteoporosis development, bone fracture, folate metabolism and genetic polymorphisms of MTHFR has been considered in many studies [14-17]. However to our best knowledge there are only a few studies considered the contribution of folate receptor and reduced folate carrier polymorphisms in the osteopenia and osteoporosis development. One of them is the study of Urano et al. performed in population of 851 Japanese postmenopausal women. The authors investigated single nucleotide polymorphism genotype of mitochondrial inner membrane folate transporter (SLC25A32) and plasma homocysteine or folate levels. In the studied group of women the AA genotype was connected with higher rate and earlier onset of incident fractures than the other genotypes. The results reveal that the SLC25A32 gene polymorphism could be a risk factor for lower folate concentration and future fracture in this group of women [18].

Facts mentioned above prove the important role of proper folate cycle in the risk, etiology and the course of osteoporosis. That is why in the presented study we aimed to estimate the role of polymorphisms of SLC19A1 and FOLR3 genes in methionine-folate pathway and their influence on the etiology of osteoporosis. And as far as we know this is the first research concerning that issue.

Obtained in our investigation results reveal the statistically significant overrepresentation of mutated GG genotype of FOLR3 (rs11235449) polymorphism in women with osteopenia what shows its protective role in this disturbance development. Additionally the statistically significant overrepresentation of wild-type GG genotype and wild-type G allele of SLC19A1 (rs3788200) polymorphism in women with osteopenia indicated its possible role in this disease development.

Probably more comprehensive research on that issue is needed to confirm these results. However, 
Table 1

Characteristics of the study population (perimenopausal women with osteopenia, osteoporosis, and normal T-score)

\begin{tabular}{|c|c|c|c|c|c|c|}
\hline & & \multirow{2}{*}{$\mathrm{P}$} & \multirow{2}{*}{ Mean } & \multirow{2}{*}{ SEM } & \multicolumn{2}{|c|}{$95 \% \mathrm{CI}$} \\
\hline & & & & & Lower limit & Upper limit \\
\hline \multirow[t]{4}{*}{ T-score } & Osteopenia & $0.04^{\mathrm{a}}$ & -1.8520 & 0.06212 & -1.9072 & -1.7530 \\
\hline & Osteoporosis & $<0001^{\mathrm{b}}$ & -3.1640 & 0.05627 & -3.2757 & -3.0522 \\
\hline & Controls & & 0.0779 & 0.11321 & -0.1482 & 0.3040 \\
\hline & Total & & -1.8138 & 0.08072 & -1.9727 & -1.6549 \\
\hline \multirow[t]{4}{*}{ Z-score } & Osteopenia & $0.117^{\mathrm{a}}$ & -0.8448 & 0.08470 & -1.0143 & -0.6754 \\
\hline & Osteoporosis & $<0001^{\mathrm{b}}$ & -3.5691 & 1.94626 & -7.4572 & 0.3190 \\
\hline & Controls & & 0.6425 & 0.19620 & 0.2423 & 1.0427 \\
\hline & Total & & -1.6696 & 0.81499 & -3.2794 & -0.0597 \\
\hline \multirow[t]{4}{*}{ Weight $[\mathrm{kg}]$} & Osteopenia & $0.026^{\mathrm{a}}$ & 65.1721 & 0.99502 & 63.2022 & 67.1420 \\
\hline & Osteoporosis & $0.001^{\mathrm{b}}$ & 61.2088 & 0.93755 & 59.3462 & 63.0714 \\
\hline & Controls & & 68.7273 & 1.49288 & 65.7458 & 71.7088 \\
\hline & Total & & 64.7204 & 0.65801 & 63.4251 & 66.0157 \\
\hline \multirow[t]{4}{*}{ Height $[\mathrm{cm}]$} & Osteopenia & $0.08^{\mathrm{a}}$ & 162.6311 & 0.45083 & 161.7386 & 163.5237 \\
\hline & Osteoporosis & $0.01^{\mathrm{b}}$ & 160.2527 & 0.52869 & 159.2024 & 161.3031 \\
\hline & Controls & & 163.0758 & 0.73612 & 161.6056 & 164.5459 \\
\hline & Total & & 161.9606 & 0.32149 & 161.3277 & 162.5934 \\
\hline \multirow[t]{4}{*}{ BMI } & Osteopenia & $0.04^{\mathrm{a}}$ & 24.6445 & 0.35747 & 23.9368 & 25.3522 \\
\hline & Osteoporosis & $0.04^{\mathrm{b}}$ & 23.7879 & 0.31784 & 23.1564 & 24.4193 \\
\hline & Controls & & 25.8802 & 0.55665 & 24.7685 & 26.9919 \\
\hline & Total & & 24.6574 & 0.23299 & 24.1988 & 25.1161 \\
\hline \multirow[t]{4}{*}{ Age [years] } & Osteopenia & $0.54^{\mathrm{a}}$ & 53.2377 & 0.73506 & 51.7825 & 54.6930 \\
\hline & Osteoporosis & $0.014^{\mathrm{b}}$ & 56.0643 & 0.74650 & 54.5883 & 57.5403 \\
\hline & Controls & & 53.3788 & 1.01176 & 51.3582 & 55.3994 \\
\hline & Total & & 54.4726 & 0.47138 & 53.5452 & 55.3999 \\
\hline \multirow[t]{4}{*}{ Birth weight $[\mathrm{g}]$} & Osteopenia & $0.026^{\mathrm{a}}$ & 3226.7857 & 77.68484 & 3067.3896 & 3386.1818 \\
\hline & Osteoporosis & $0.005^{b}$ & 3141.2500 & 134.07981 & 2855.4656 & 3427.0344 \\
\hline & Controls & & 3628.9474 & 110.29173 & 3397.2330 & 3860.6617 \\
\hline & Total & & 3326.3492 & 63.20235 & 3200.0095 & 3452.6889 \\
\hline \multirow{4}{*}{$\begin{array}{l}\text { Years of } \\
\text { reproduction }\end{array}$} & Osteopenia & $0.724^{\mathrm{a}}$ & 36.2000 & 0.63682 & 34.9257 & 37.4743 \\
\hline & Osteoporosis & $0.528^{\mathrm{b}}$ & 35.6154 & 0.62160 & 34.3736 & 36.8572 \\
\hline & Controls & & 36.3750 & 0.94586 & 34.4459 & 38.3041 \\
\hline & Total & & 35.9936 & 0.40144 & 35.2007 & 36.7866 \\
\hline \multirow{4}{*}{$\begin{array}{l}\text { Age of first } \\
\text { menstruation }\end{array}$} & Osteopenia & $0.636^{\mathrm{a}}$ & 13.1167 & 0.30908 & 12.4982 & 13.7351 \\
\hline & Osteoporosis & $0.754^{\mathrm{b}}$ & 12.9385 & 0.26843 & 12.4022 & 13.4747 \\
\hline & Controls & & 13.3750 & 0.33224 & 12.6974 & 14.0526 \\
\hline & Total & & 13.0955 & 0.17517 & 12.7495 & 13.4416 \\
\hline \multirow{4}{*}{$\begin{array}{l}\text { Age of last } \\
\text { menstruation }\end{array}$} & Osteopenia & $0.069^{\mathrm{a}}$ & 49.2099 & 0.49588 & 48.2230 & 50.1967 \\
\hline & Osteoporosis & $0.058^{\mathrm{b}}$ & 48.1585 & 0.54804 & 47.0681 & 49.2490 \\
\hline & Controls & & 50.1707 & 0.68512 & 48.7860 & 51.5554 \\
\hline & Total & & 48.9804 & 0.32876 & 48.3322 & 49.6286 \\
\hline \multirow{4}{*}{$\begin{array}{l}\text { Number of } \\
\text { pregnancies }\end{array}$} & Osteopenia & $0.869^{\mathrm{a}}$ & 1.8852 & 0.09821 & 1.6908 & 2.0797 \\
\hline & Osteoporosis & $0.902^{\mathrm{b}}$ & 1.9560 & 0.13525 & 1.6873 & 2.2247 \\
\hline & Controls & & 1.9394 & 0.14940 & 1.6410 & 2.2378 \\
\hline & Total & & 1.9211 & 0.07075 & 1.7819 & 2.0604 \\
\hline Years after & Osteopenia & $0.854^{\mathrm{a}}$ & 7.1833 & 0.77769 & 5.6272 & 8.7395 \\
\hline menopause & Osteoporosis & $0.001^{\mathrm{b}}$ & 10.6308 & 0.71305 & 9.2063 & 12.0553 \\
\hline & Controls & & 7.0313 & 0.98832 & 5.0156 & 9.0469 \\
\hline & Total & & 8.5796 & 0.48209 & 7.6273 & 9.5319 \\
\hline BMD & Osteopenia & $0.986^{\mathrm{a}}$ & 0.9674 & 0.02003 & 0.9276 & 1.0072 \\
\hline $\mathrm{L} 2-\mathrm{L} 4\left[\mathrm{~g} / \mathrm{cm}^{2}\right]$ & Osteoporosis & $0.944^{\mathrm{b}}$ & 0.9752 & 0.01495 & 0.9456 & 1.0048 \\
\hline & Controls & & 0.9694 & 0.02186 & 0.9254 & 1.0133 \\
\hline & Total & & 0.9713 & 0.01066 & 0.9503 & 0.9923 \\
\hline BMD & Osteopenia & $0.965^{\mathrm{a}}$ & 80.9022 & 1.71939 & 77.4868 & 84.3175 \\
\hline L2-L4 YA [\%] & Osteoporosis & $0.982^{b}$ & 81.2783 & 1.24077 & 78.8203 & 83.7362 \\
\hline & Controls & & 81.0204 & 1.77293 & 77.4557 & 84.5851 \\
\hline & Total & & 81.0938 & 0.89537 & 79.3305 & 82.8570 \\
\hline BMD L2-L4 & Osteopenia & $0.989^{a}$ & 89.1304 & 1.82717 & 85.5010 & 92.7599 \\
\hline AM [\%] & Osteoporosis & $0.968^{b}$ & 89.5043 & 1.23064 & 87.0665 & 91.9422 \\
\hline & Controls & & 89.7755 & 1.93765 & 85.8796 & 93.6714 \\
\hline & Total & & 89.4219 & 0.93156 & 87.5873 & 91.2564 \\
\hline
\end{tabular}

a- Comparison between the groups with osteopenia and normal T-score (one-way ANOVA)

b- Comparison between the groups with osteoporosis and normal T-score (one-way ANOVA) 
Table 2

Distribution of FOLR3 (rs11235449) polymorphism in patients with osteopenia and in control group

\begin{tabular}{|c|c|c|c|c|c|c|c|c|c|c|c|c|}
\hline \multirow[b]{2}{*}{ Genotype } & \multicolumn{5}{|c|}{ Osteoporosis } & \multicolumn{5}{|c|}{ Osteopenia } & \multicolumn{2}{|c|}{ Control } \\
\hline & $\begin{array}{l}\text { Observed } \\
\text { value } \\
\mathrm{n}[\%]\end{array}$ & $\begin{array}{l}\text { Expected } \\
\text { value } \\
{[\%]}\end{array}$ & OR & $95 \% \mathrm{CI}$ & $\mathrm{P}$ & $\begin{array}{l}\text { Observed } \\
\text { value } \\
\mathrm{n}[\%]\end{array}$ & $\begin{array}{l}\text { Expected } \\
\text { value } \\
{[\%]}\end{array}$ & OR & $95 \%$ CI & $\mathrm{P}$ & $\begin{array}{l}\text { Observed } \\
\text { value } \\
\mathrm{n}[\%]\end{array}$ & $\begin{array}{l}\text { Expected } \\
\text { value } \\
{[\%]}\end{array}$ \\
\hline $\mathrm{AA}$ & $52(15.6)$ & 20.8 & 1.05 & $0.64-1.72$ & 0.472 & $19(17.4)$ & 17.0 & 1.19 & $0.61-2.28$ & 0.337 & $35(15.0)$ & 14.9 \\
\hline AG & $162(48.6)$ & 49.6 & 0.97 & $0.68-1.38$ & 0.471 & $52(47.7)$ & 48.5 & 1.02 & $0.63-1.64$ & 0.512 & $110(47.2)$ & 47.4 \\
\hline GG & $119(35.7)$ & 29.6 & 0.92 & $0.64-1.32$ & 0.342 & $38(34.9)$ & 34.5 & 0.61 & $0.38-1.00$ & 0.025 & $88(37.8)$ & 37.7 \\
\hline Total & $333(100)$ & 100.00 & - & - & - & $109(100)$ & 100.00 & - & - & - & $233(100)$ & 100.00 \\
\hline \multicolumn{13}{|l|}{ Alleles } \\
\hline A & $266(39.9)$ & - & 1.06 & $0.82-1.36$ & 0.351 & $90(41.3)$ & - & 1.12 & $0.79-1.58$ & 0.281 & $180(38.6)$ & - \\
\hline G & $400(60.1)$ & - & 0.95 & $0.74-1.21$ & 0.351 & $128(58.7)$ & - & 0.89 & $0.63-1.26$ & 0.281 & $286(61.4)$ & - \\
\hline Total & $666(100.00)$ & - & - & - & - & $218(100.00)$ & - & - & - & - & $466(100.00)$ & - \\
\hline
\end{tabular}

Table 3

Distribution of SLC19A1 (rs3788200) polymorphism in patients with osteopenia and in control group

\begin{tabular}{|c|c|c|c|c|c|c|c|c|c|c|c|c|}
\hline \multirow[b]{2}{*}{ Genotype } & \multicolumn{5}{|c|}{ Osteoporosis } & \multicolumn{5}{|c|}{ Osteopenia } & \multicolumn{2}{|c|}{ Control } \\
\hline & $\begin{array}{l}\text { Observed } \\
\text { value } \\
\mathrm{n}[\%]\end{array}$ & $\begin{array}{l}\text { Expected } \\
\text { value } \\
{[\%]}\end{array}$ & OR & $95 \% \mathrm{CI}$ & $\mathrm{P}$ & $\begin{array}{l}\text { Observed } \\
\text { value } \\
\mathrm{n}[\%]\end{array}$ & $\begin{array}{l}\text { Expected } \\
\text { value } \\
{[\%]}\end{array}$ & OR & $95 \% \mathrm{CI}$ & $\mathrm{P}$ & $\begin{array}{l}\text { Observed } \\
\text { value } \\
\mathrm{n}[\%]\end{array}$ & $\begin{array}{l}\text { Expected } \\
\text { value } \\
{[\%]}\end{array}$ \\
\hline GG & $99(29.7)$ & 29.0 & 1.19 & $0.81-1.77$ & 0.204 & $39(35.8)$ & 32.4 & 1.57 & $0.93-2.63$ & 0.046 & $61(26.2)$ & 25.2 \\
\hline GA & $161(48.3)$ & 49.7 & 1.01 & $0.71-1.43$ & 0.508 & $46(42.2)$ & 49.0 & 0.79 & $0.48-1.28$ & 0.185 & $112(48.1)$ & 50.0 \\
\hline AA & 73 (21.9) & 21.3 & 0.81 & $0.54-1.22$ & 0.169 & $24(22.0)$ & 18.6 & 0.81 & $0.45-1.43$ & 0.271 & $60(25.8)$ & 24.8 \\
\hline Total & $333(100)$ & 100.00 & - & - & - & $109(100)$ & 100.00 & - & - & - & $233(100)$ & 100.00 \\
\hline \multicolumn{13}{|l|}{ Alleles } \\
\hline G & $359(53.9)$ & - & 1.16 & $0.91-1.48$ & 0.122 & $124(56.9)$ & - & 1.31 & $0.93-1.83$ & 0.061 & $234(50.2)$ & - \\
\hline A & $307(46.1)$ & - & 0.86 & $0.68-1.10$ & 0.122 & $94(43.1)$ & - & 0.76 & $0.54-1.07$ & 0.061 & $232(49.8)$ & - \\
\hline Total & $666(100.00)$ & - & - & - & - & $218(100.00)$ & - & - & - & - & $466(100.00)$ & - \\
\hline
\end{tabular}

correlation of impaired folate cycle and the risk of osteoporosis development seems to be obvious. It should be kept in mind that identification of risk factors of osteoporosis is of high importance. It would allow to recognize subjects of high risk of osteoporosis at which inexpensive and effective treatment and prophylaxis could be started.

\section{CONCLUSIONS}

In our research the protective role of mutated GG genotype of FOLR3 (rs11235449) polymorphism to osteopenia progress and possible role of wildtype GG genotype and wild-type G allele of SLC19A1 (rs3788200) polymorphism in osteopenia development was shown.

\section{ACKNOWLEDGEMENTS}

The study was supported by statutory projects of the Institute of Natural Fibres and Medicinal Plants in Poznań, Poland and Poznań University of Medical Sciences.

Conflict of interest: Authors declare no conflict of interest.

\section{REFERENCES}

1. Akpolat V, Bilgin HM, Celik MY, Erdemoglu M, Isik B. An evaluation of nitric oxide, folate, homocysteine levels and lipid peroxidation in postmenopausal osteoporosis. Adv Clin Exp Med 2013; 22(3):403-409. 
2. Tyagi N, Kandel M, Munjal C, Qipshidze N, Vacek JC, Pushpakumar SB, et al. Homocysteine mediated decrease in bone blood flow and remodeling: role of folic acid. J Orthop Res 2011; 29(10):1511-1516.

3. Alley RA, Chen EL, Beyer TD, Prinz RA. Does homocysteine contribute to bone disease in hyperparathyroidism? Am J Surg 2008; 195:374-377.

4. Herrmann M, Taban-Shomal O, Muller S, Gunter L, Hübner U, Böhm M, et al. Hyperhomocysteinemia - the biochemical link between a weak heart and brittle bones? Clin Lab 2006; 52:137-147.

5. LeBoff MS, Narweker R, LaCroix A, Wu L, Jackson R, Lee J, et al. Homocysteine levels and risk of hip fracture in postmenopausal women. J Clin Endocrinol Metab 2009; 94:1207-1213. doi: http://dx.doi.org/10.1210/jc.2008-1777

6. Albert CM, Cook NR, Gaziano JM, Zaharris E, MacFadyen J, Danielson E, et al. Effect of folic acid and $\mathrm{B}$ vitamins on risk of cardiovascular events and total mortality among women at high risk for cardiovascular disease: a randomized trial. JAMA. 2008; 299(17):2027-2036. doi: http:// dx.doi.org/10.1001/jama.299.17.2027

7. Bostom AG, Selhub J, Jacques PF, Rosenberg IH. Power Shortage: clinical trials testing the homocysteine hypothesis' against a background of folic acid-fortified cereal grain flour. Ann Intern Med 2001; 135(2):133-137.

8. Yang J, Hu X, Zhang Q, Cao H, Wang J, Liu B. Homocysteine level and risk of fracture: a meta-analysis and systematic review. Bone 2012; 51(3):376-382. doi: http://dx.doi.org/10.1016/j. bone.2012.05.024

9. van Meurs JB, Dhonukshe-Rutten RA, Pluijm SM, van der Klift $\mathrm{M}$, de Jonge $\mathrm{R}$, Lindemans J, et al. Homocysteine levels and the risk of osteoporotic fracture. N Engl J Med 2004; 350(20):2033-2041. doi: http://dx.doi.org/10.1056/NEJMoa032546

10. Kuroda T, Tanaka S, Saito M, Shiraki Y, Shiraki M. Plasma level of homocysteine associated with severe vertebral fracture in postmenopausal women. Calcif Tissue Int 2013; 93(3):269-275. doi: http:// dx.doi.org/10.1007/s00223-013-9754-2

11. Nilsson K, Gustafson L, Isaksson A, Hultberg B.
Plasma homocysteine and markers of bone metabolism in psychogeriatric patients. Scand J Clin Lab Invest 2005; 65(8):671-680. doi: http://dx.doi. org/10.1080/00365510500348153

12. Gerdhem P, Ivaska KK, Isaksson A, Pettersson K, Vaananen HK, Obrant KJ, et al. Associations between homocysteine, bone turnover, BMD, mortality, and fracture risk in elderly women. J Bone Miner Res 2007; 22(1):127-34. doi: http://dx.doi. org/10.1359/jbmr.061003

13. Bailey RL, Looker AC, Lu Z, Fan R, Eicher-Miller HA, Fakhouri TH, et al. B-vitamin status and bone mineral density and risk of lumbar osteoporosis in older females in the United States. Am J Clin Nutr 2015; 102(3):687-694. doi: http:// dx.doi.org/10.3945/ajcn.115.108787

14. Golbahar J, Hamidi A, Aminzadeh MA, Omrani GR. Association of plasma folate, plasma total homocysteine, but not methylenetetrahydrofolate reductase C667T polymorphism, with bone mineral density in postmenopausal Iranian women: a cross-sectional study. Bone 2004; 35(3):760-5.

15. Gjesdal CG, Vollset SE, Ueland PM, Refsum H, Meyer HE, Tell GS. Plasma homocysteine, folate, and vitamin B 12 and the risk of hip fracture: the hordaland homocysteine study. J Bone Miner Res 2007; 22(5):747-756.

16. Shiraki M, Urano T, Kuroda T, Saito M, Tanaka S, Miyao-Koshizuka M, et al. The synergistic effect of bone mineral density and methylenetetrahydrofolate reductase (MTHFR) polymorphism (C677T) on fractures. J Bone Miner Metab 2008; 26(6):595-602.

17. Abrahamsen B, Madsen JS, Tofteng CL, Stilgren L, Bladbjerg EM, Kristensen SR, et al. A common methylenetetrahydrofolate reductase (C677T) polymorphism is associated with low bone mineral density and increased fracture incidence after menopause: longitudinal data from the Danish osteoporosis prevention study. J Bone Miner Res 2003; 18(4):723-729.

18. Urano T, Shiraki M, Saito M, Sasaki N, Ouchi Y, Inoue S. Polymorphism of SLC25A32, the folate transporter gene, is associated with plasma folate levels and bone fractures in Japanese postmenopausal women. Geriatr Gerontol Int 2014; 14(4):942-946. doi: http://dx.doi.org/10.1111/ggi.12201 